\title{
Is a New Generation of Managers Likely to Come to Small Towns of Ukraine? (An interview with Mykola Liashenko)
}

\author{
Mykola Liashenko \\ Doctor of Law, Deputy of the Kyiv Oblast Rada VII Convocation (Kyiv, Ukraine) \\ E-mail: 0933451777@ukr.net
}

\section{Sergii Rudenko}

Doctor of Philosophy, Associate Professor, Taras Shevchenko National University of Kyiv

(Kyiv, Ukraine)

E-mail: rudenkosrg@gmail.com

ORCID: 0000-0001-9069-0989

There are about 350 small towns in Ukraine what makes around $3 / 4$ of the total number of towns. Small towns comprise approximately 13\% of the Ukrainian population, with about 20 million citizens related to them. Small towns are divided by districts and regions almost equally - 61-75 of small towns, or 17,4-21,4\% of the total number of towns. The greatest number of small towns are located in the regions of Lviv - 39, Donetsk - 35, Luhansk - 26, Kyiv - 19, Ternopil - 17 and Vinnytsia - 17 small towns.

The decentralization reform has opened to Ukrainian small towns new opportunities and development prospects. Today, to realize these opportunities small towns badly need a new generation of managers capable of unlocking their political, economic, social and cultural potential. Yet, do young Ukrainian managers, politicians and public leaders want to work in small towns of our country? The answers to these questions are given by Mykola Liashenko, a public deputy of Kyiv regional council (VII convocation) in an interview to Sergii Rudenko.

Key Words: Ukrainian small towns, decentralization reform, manager, Ukrainian political elite, new generation.

Received May 12, 2018; accepted May 30, 2018

Ukrainian Policymaker, Volume 2, 2018: 56-62

DOI: $10.29202 /$ up/2/8

(C) Liashenko, Mykola, 2018

(C) Rudenko, Sergii, 2018 
Is a New Generation of Managers Likely to Come to Small Towns of Ukraine?

by Mykola Liashenko and Sergii Rudenko

Dear Mr. Liashenko, first of all, we would like to know your opinion as an experienced specialist and practicing manager concerning the future of small towns of Ukraine and the key problems of their current development. It is the small towns that are peculiar "indicators" of country's development and the life level of its citizens.

No doubt, it is the small towns that are peculiar "indicators" of country's development and the life level of its citizens. Therefore, the developed social infrastructure, available preschool educational institutions, schools, medical institutions and the rest of communication transportation infrastructure give a citizen an opportunity to comfortably provide for his or her vitally important needs. A person who is not overloaded with family life problems feels freer, has wider opportunities, more space time to be spent for positive emotions. This makes him feel happy and feel a part of society and state.

Very unfortunately, small towns do not have sufficient managerial power. A great misbalance of responsibilities and opportunities, imperfect legislation as to realization of managerial decisions at local level has a negative impact on a community's development.

In fact, a small town has its own government body, with a state district administration controlling a number of social objects and public utility companies. There are cases when such a town also has communal property objects and enterprises of regional importance that cover the citizens' needs but are not controlled by local self-government bodies. All the Soviet past superstructures complicate the processes of taking necessary managerial decisions and using budget funds. For example, a town of Vyshneve, Kyievo-Svyatoshyn district, Kyiv region, has been constructing the second building of general secondary school No 1 for twelve years. The school is controlled by the Kyievo-Svyatoshyn district state administration that passed the employer's functions to Kyiv regional administration. The bureaucratic red-tape, in particular sessions of the local council, the district council, the region council, signing three-level order documents and the purchase procedure cause the inefficient use of funds and a delay in building of this socially important object. And this is only a small example.

Inefficient use of budget funds and corruption hamper the small town development. According to the 2017 statistics of Ukraine's Ministry of Internal Affairs, there were brought to administrative account for corruption offences 332 local self-government officials. There were started criminal proceedings against 124 local self-government officials. The amount of damage to the state and the territorial community according to completed criminal proceedings makes 14833248207 hrn., of which 249566639 hrn. was reimbursed [Zvit, 2017; Bazaluk, 2017]

Creation of united territorial communities (UTC) is aimed at leaving more funds at local level, as well as receiving additional budget transfers. At the same time, this involves taking a responsibility of supporting the local infrastructure. Irrational use of local natural resources and mineral resources in particular, receiving lower rent payment for their use and illegal mining cause receiving lower local budget funds which could be used for further development.

There is lack of financial resources and a complicated order of engaging credit funds for development of local economics and infrastructure. Though the opening of credit resource involves risks, attracting additional funds, with actual deficiency of investment inside the country and investments from abroad, could improve the economic situation in small towns, if the funds are directed to development of the real economic sector, improvement of management quality, tourism and power engineering growth. Money return is guaranteed by tax receipts and funds from realized projects. 
Small towns have low-developed water supply and drainage systems, as well as heat- and power supply systems. Low-developed is the social and cultural base - lack of recreations, such as cinemas, theatres, museums, trade and entertainment centres, lack of sport and other clubs providing opportunities for young people's development. Instead, there is club culture which does not always have a positive impact on health and development of social relations of the youth.

Small towns have almost no job places for highly-qualified specialists. Attempts to create technological parks could give a positive result, if there are funds and desire of local authorities to launch a project.

We should not forget about labour emigration. According to the Ministry of Internal Affairs, about $5 \mathrm{mln}$. Ukrainians are working abroad [Za kordonom, 2017]. The survey by the Research \& Branding Group in February, 2017, has shown that emigrating for work more often were 30-39-aged men than women, rural citizens and west-Ukrainian citizens. Labour emigrants were more frequently at the age of 18-39. Much more frequent emigrants were people from central and western regions than those of eastern and southern regions. In the near time, $14 \%$ of Ukrainians are planning to leave abroad, of which $11 \%$ are going to come back, whereas $3 \%$ are going there for permanent residence. Around $80 \%$ of Ukrainian citizens are not planning to go abroad in the nearest future. We should take into account that 18-30-year-old young people are potential labour emigrants [Ukraintsy, 2018].

Small towns have a number of advantages. They are a controlled pace of life, closeness to nature, potential green tourism, better ecology, opportunities for alternative power source development, possible funds attraction to agriculture since there is free land in suburban area. The use of these advantages can help small towns to partially solve their problems.

Statistically, every fourth citizen of the Earth lives in a million-plus city. According to experts' prognoses, at the end of the $21^{\text {st }}$ century more than $80 \%$ of our planet's population will live in large cities. By the year 2030 the Earth will have got around 40 city agglomerations, with more than $10 \mathrm{mln}$. people each [Serhiyenko, 2017].

\section{What managers do Ukrainian small towns of today need, what competences are they to have?}

With extended rights and obligations, a local self-government authority does no longer need a statistician, a party careerist manager. Small towns call for a new manager meeting the criteria of today, not only for a young-aged manager, but for a manager having new world outlook, new views on development of modern society and community. At the same time, he or she should be a diplomat, a financier and a business executive, able to manage the community's resources and to attract and use outside opportunities.

A manager is to have the following competences and qualities:

a) Managerial work experience, at public service, and experience of attracting servants competent in business and project management, legal education, competence in regulatory and legal acts and mechanisms of their adoption to be able to follow the "letter of the law";

b) Political and economic competence enabling to understand better the economic situation and political arrangements, since social and economic transformations require not only wish but political will as well;

c) Knowledge of finance and budget business, budget code in particular. A manager will administer the town's funds and is required to be able to set priorities and balance 
the resources available. He or she should understand that without supporting the local business, revising the production, developing and facilitating innovations, it will be impossible to increase town's tax receipts;

d) A good command of the national language;

e) Basic knowledge and skills in psychology. Working with people requires searching for ways of dealing with them. However, a manager should not be just a psychologist, but also a diplomat, able to accommodate the confronting parties and find a compromise, to hold negotiations as well;

f) Image of a manager and a public servant as a whole, what is very important in conditions of Ukraine's EU integration. A manager of today is not only a specialist but a man of wide horizon, a man of high moral and business qualities;

g) Knowledge of etiquette, which will help to behave with dignity, both in negotiations and in everyday life.

The above features should be added with such important factors as ability to take decisions and be responsible for them. And, what may be the most important, to be able to gather a team and consolidate it around himself. Not always one person can have all perfect skills, but it means that he or she should be at least good at them. Here one needs a team of experts.

Is there a candidates' pool of managers in small town communities, taking into account the fact that talented young people prefer for their own development the capital city and large cities of Ukraine?

Yes, there is a very big problem of not only candidates' pool but of human resources in general. Young people able to take responsibility migrate not only to the capital and million-plus cities but also abroad. The young who need changes and local accommodation improvements right now, naturally strive for the best. Talented, spirited and communicable young people leave towns what has a negative impact not only on communities' development but also on formation of public opinion and the state.

According to the Central Civil Service, as of January,1, 2001, there were under 30-yearold male civil servants, including local self-government authorities $-18,4 \%$, female civil servants - 24,5\%. In his monograph "The Staff in Regions of Ukraine: Formation and Development", Vitally Oluyko noted that females under the age of 30 make only $26 \%$ of district and $20,9 \%$ of regional state administrations, $17,6 \%$ of females work in local selfgovernment bodies and $25,5 \%$ of them work in territorial bodies of ministries and departments. As of January, 1, 2000, out of 244268 civil servants (not including law enforcement agencies and tax administrations) only 54452 were civil servants [Oluyko, 2001].

According to the Central Civil Service of Ukraine, in early 2004 young people in state authorities made around a quarter of their total number [Plakhotnyuk, 2005].

According to the Central Electoral Commission, after the 2015 regular local elections, following the Revolution of Dignity, the posts of chief executives in towns, settlements and villages were held by young people under 20 years old $-0,01 \%$, aged $21-30-4,96 \%$, aged $31-40-15,19 \%$, aged $41-50-38,04 \%$, aged $51-60-37,08 \%$, aged $61-80-4,68 \%$. As we can see, the main part of them are people from 40 to 60 years old, while young and middleaged people under 40 make $20,15 \%$, which means that local authorities have not become younger [Tsentralna, 2015]. Our country currently needs people with new world outlook, people who are not afraid of new things, since it is very important in our dynamic world - 
what was significant yesterday may become history today [Rudenko et al., 2018]. As it can be seen, there is local staff available, but the age disproportion is evident: young managers under 40 think differently if compared to the elder generation. As to the young people under 30 years old, they are a new generation, the future of the Ukrainian political elite. They were born and grew in the independent Ukraine; they went through a number of economic, social and political shocks. Those who apply for government authorities realise that they are the future of the state and the nation as a whole. As time passes, the Ukrainian political elite will be renewed but the problem is in quality and qualification of the staff to come. Therefore, it is necessary to start training future managers right today, attracting the young not only in word. The main part of future managers should be both local executives and additional non-local staff, to support the country's integrity: a vivid example is Catalonia whose government started decentralization tendencies and territorial separation from Spain.

To raise the management quality at local level, one needs to start staff training and retraining and training. The local candidates' pool does not meet the requirements of time and social and economic conditions, both at local level and in the country as a whole. A way out is re-training courses, teaching modern theory of management, economics, banking, accounting, project management, the English language courses, budget code studies, etc., as well as gaining practical experience and getting traineeship both in Ukraine and abroad. It is necessary to improve the education system which trains the managerial staff by bringing it down to earth [Liashenko \& Rudenko, 2018].

\section{Do young people want to work as small town managers?}

Here, as it says, we should "sort the wheat from the chaff." There are people, especially young ones, who are busy with the so-called political populism. They cannot really manage a town; they go to government for personal reasons, for personal enrichment. They are not able to develop a town. In addition, capable young men hesitate in taking town management decisions.

Why do not young people having political, managerial and leadership abilities want to realize them in small towns of Ukraine?

The problem is that talented young people, patriotic people, able managers, are not morally ready to take a responsibility, regarding the imperfect legal mechanism of managerial decision realisation. There is a person, who, with his own mind and ambitions, is able to realise real decisions, but "the system" prevents him from doing this. These are cases after which a person feels depressed, unprotected, wanting to leave not only his native town but the country as well.

One should also take into account the world tendency of absorption by large cities of small towns, since large cities can offer more career and business opportunities, more comfortable living conditions - transportation, public utility services, medicine, education. The larger the number of people is, the larger the potential market is, if speaking about business. Regarding innovations, this is an opportunity to create a team launching a start-up and find the funds. Small towns cannot currently offer such opportunities and this is a problem [Naumenko, 2018].

Can this problem be solved today, if yes, in which way? 
Yes, it is possible. One needs only to set clear "game rules." To my mind, all the issues concerning town's life support should be controlled by a local manager with confirmed rights and financial resources guaranteed by tax receipts. It is necessary to simplify decision realization mechanisms, with legal deregulation. There should be given an opportunity to solve problems with simple and understandable decisions. It is important to solve at government level the problems with monopolists, to improve a town's life support, for example, by creating a power supply market enabling a community and its citizens to choose service providers, what will positively influence the service payments and service quality.

According to the survey made by the Research \& Branding Group in February 2018, the main criterion in job selection was a good salary (58\%). The five most important job selection criteria also included timely salary payment (23\%), comfortable working schedule (21\%), convenient workplace location (17\%) and a social package (16\%) [Ukraintsy, 2018].

As one can see, the main job selection criterion is salary. A person who is going to work as an official and who receives a very little salary, will operate million-worth amounts of money or will get other enrichment opportunities, as it says to "settle the issue". Of course, there are populist managers, who work for minimal salary, hiding behind the fact that they had left their business and do not need finance, but still solve their own problems. A burning issue is salary charging, since under law a town's chief salary is assigned by the local council, adding premium to his fixed salary.

With time, small towns are to turn into large cities, urbanization cannot be stopped, and that is why it needs to be "headed". People need salary, social infrastructure and support of innovation business projects. Then small towns will grow into large cities with not only opportunities but also the number of people living in them.

\section{[C] References}

Bazaluk, Oleg. Corruption in Ukraine: Rulers' Mentality and the Destiny of the Nation, Geophilosophy of Ukraine. Cambridge Scholars Publishing, 2016.

Derun, Tetyana. Problems of Small Town Development in Conditions of Social and Economic Transformation of the Ukrainian Society. Derzhavne upravlinnya: teoriya ta praktyka. 2, 2009. http://www.nbuv.gov.ua/e-journals/Dutp/2009_2/

Liashenko, Iryna and Sergii Rudenko. The Management Features of the University Preparatory Department. Scientific Bulletin of National Mining University, 1, 2018: 163-168.

Naumenko, Raisa. Philosophy of Public Governance: Manpower Policy of Modern Ukraine in the Context of Globalization. Philosophy and Cosmology, Volume 20, 2018: 106-112. DOI: $10.29202 /$ phil-cosm/20/9

Oluyko, Vitaliy. Kadry v rehioni Ukrayiny: stanovlennya ta rozvytok. Kyiv: Naukovyy svit, 2001. - $236 \mathrm{~s}$.

Plakhotnyuk, N.H. Protsedury zaluchennya molodi na derzhavnu sluzhbu: orhanizatsiinopravovyi aspect [Procedures of Attracting Young People to Civil Service: Organizational and Legal Aspects]. Universitetskiye nauchnyye zapiski: Zhurnal Khmel'nits. un-ta. 1/2, 2005: 296-301

Rudenko, S., Sapeńko, R., Bazaluk, O. and Tytarenko, V. Management Features of International Educational Projects Between Universities of Poland and Ukraine. Naukovyi Visnyk Natsionalnoho Hirnychoho Universytetu. 2, 2018: 142-147. DOI: 10.29202/ nvngu/2018-2/21 
Serhiyenko, O. Pro maibutnie ukraiinskykh mist [On the Future of Ukrainian Cities and Towns]. Dzerkalo Tyzhnia, 2017. https://dt.ua/internal/pro-maybutnye-ukrayinskihmist-251688_html

Tsentralna vyborcha komissiya, mistsevi vybory, Ukraiina-2015 [Central Electoral Commission, 2015 local elections of Ukraine] [Electronic Resource]/ http://www.cvk.gov.ua/pls/ vm2015/PVM148?PT001F01=100\&pt00_t001 f01=100\&rej=0\&pstr=6\#

Ukraintsy i rabota za granitsei [Ukrainians and Overseas Work], Research \& Branding Group, 06.03.2018. http://rb.com.ua/blog/ukraincy-i-rabota-za-granicej/

Za kordonom pratsyuye $5 \mathrm{mln}$ ukraiintsiv. Derzhsluzhba zainyatosti. [5 mln Ukrainians Are Working Abroad, State Employment Service] Dzerkalo Tyzhnia, 2017. https://dt.ua/UKRAINE/za-kordonom-pracyuye-5-mln-ukrayinciv-derzhsluzhbazaynyatosti-232858_html

Zin, E. A. Regional Economics. Kyiv: Professional, 2007. — 528 p.

Zvit pro stan protydiyi koruptsiyi - 2017, Ministerstvo Vnutrishnikh Sprav [2017 Ministry of Internal Affairs Report on Corruption Prevention]: [Electronic Resource] http://mvs. gov.ua/ua/pages/274_Statistika.htm 